\title{
Cultural Evaluation of Perceptual Problems in Modern Turkish Painting
}

\author{
Tuncay ÇİÇEK ${ }^{1}$
}

\begin{abstract}
The development of modern art in the historical process, in contrast to the hundreds of years of history of Western countries, there is an average of one hundred and fifty years in Turkish painting. Despite this important distinction, the point that Turkish painting has reached today is a level that cannot be underestimated. Despite all this, Turkish painting still has not reached the place it should be and Turkish painters have not produced works that can be called "masterpieces". The main reason for this situation is thought to be perceptual problematic in this study. Because Turkish painting was limited to three big cities such as Ankara, Istanbul and Izmir. Therefore, in general, painters did not stay very close to Anatolian culture, which is seen as the carrier of Turkish culture, and could not benefit from their own cultural roots as much as they should and as a result, perceptual problematic emerged because they did not interact sufficiently with their own culture. Literature review was used as a method in this research, which is based on the cultural evaluation of the perceptual problematic in modern Turkish painting. According to the results of the survey, the perceptual problematic in the cultural context began to be overcome, thanks to the painters' approach to their own culture and their synthesis of traditional and modern elements. It is thought that Turkish painting will progress and accelerate in the international platform over time. Culturally, Turks have the richest and deep-rooted heritage in the world. Therefore, it is believed that the cultural lands of the Turks, which have hosted many civilizations, will become a source of inspiration for painters over time and that the perceptual problems that have not been overcome until today will be overcome.
\end{abstract}

Key Words: Modern Turkish Painting, Problem of Perception, Culture

\section{Modern Türk Resminde Algısal Sorunsallarının Kültürel Açıdan Değerlendirilmesi}

$\ddot{O} z$

Modern sanatın tarihsel süreç içerisindeki gelişimi, Batılı ülkelerin yüzlerce senelik geçmişlerine karşılık, Türk resminde ortalama yüz- yüz elli senelik bir süreç bulunmaktadır. Bu önemli ayrıma karşılık, bugün Türk resminin ulaştığı nokta hiç de azımsanmayacak bir seviyedir. Bütün bunlara karşın Türk resmi hala olması gereken yere ulaşmamış ve Türk ressamları "baş yapıt" denilecek eserler üretmemiştir. Bu durumun temel nedeni olarak bu çalışmada algısal sorunsalın olduğu düşünülmektedir. Çünkü Türk resmi Ankara, İstanbul ve İzmir gibi genelde üç büyük şehir arasında sınırlı kalmışır. Dolayısıyla genel olarak ressamlar Türk kültürünün taşıyıcı sahası olarak görülen Anadolu kültürüne çok yakın durmayıp, kendi kültürel köklerinden olması gerektiği kadar yararlanamamıştır ve sonuçta kendi kültürleri ile yeterince etkileşimde bulunmadıkları için ortaya algısal sorunsalın çıkmıştır. Modern Türk resmindeki algısal sorunsalın kültürel açıdan değerlendirilmesi temeline dayanan bu araştırmada literatür taraması yöntem olarak kullanılmıştır. Taramanın sonuçlarına göre, gün geçtikçe ressamların kendi kültürlerine yaklaşması ve geleneksel öğelerle modern öğeleri sentezlemeleri sayesinde kültürel kapsamdaki algısal sorunsal aşılmaya başlamıştır. Zaman içerisinde Türk resminin uluslararası platformda da ilerleyip ivme sağlayacağı düşünülmektedir. Kültürel açıdan Türkler dünyadaki en zengin ve köklü mirasa sahiptirler. Dolayısıyla, pek çok medeniyete ev sahipliği eden Türklerin kültürel toprakları zaman içerisinde ressamlar içinde ilham kaynağı haline gelip bugüne dek aşılamayan algısal sorunların aşılacağına inanılmaktadır.

Anabtar Kelimeler: Modern Türk Resmi, Alg1 Sorunsalı, Kültür

Atıf İçin / Please Cite As:

Çiçek, T. (2021). Cultural evaluation of perceptual problems in modern Turkish painting. Manas Sosyal Araştırmalar Dergisi, 10(4), 2256-2266.

Geliş Tarihi / Received Date: 24.07.2021

Kabul Tarihi / Accepted Date: 06.08.2021

${ }^{1}$ Dr. Öğr. Üyesi. - Iğdır Üniversitesi Fen Edebiyat Fakültesi, alpago_25@hotmail.com

iD ORCID: 0000-0002-6833-6462 


\section{Introduction}

One of the most defined concepts is culture. Many researchers and thinkers have made various definitions of culture in the context of their own approaches. Turhan, who has worked on the subject, stated that the main determinant of both the way of life and the structure of thought, art, literature, religion, joy and entertainment in daily life is the world of culture. Throughout the entire historical process, it has been accepted as a work created by man himself by learning about the world nature and how to manage himself (Turhan, 2012, p. 38).

Culture is accepted as the way of life of a society or people. The famous theorist E.B. Tylor defines the concept of culture as a very intricate whole that includes knowledge, belief, art, morals, customs, the reserves acquired by the individual as a member of the society to which he belongs, and all other interests (Güvenç, 1996, p. 273).

The concept of culture, which is also accepted as a set of values that is transmitted from generation to generation, is the value judgments that all members of a society have in the historical process with their perceptions that meet the events. These values are kept alive by science, philosophy, art and religion (Topçu, 1998, p. 16). As it is seen, culture is a very important and necessary phenomenon for art and artists, as it is the building block of society.

In general, in almost all areas of art, the artist is nourished by the culture he/she is in. If the artist is an individual of the society he lives in, it is inevitable to see traces of the cultural structure of the society he/she lives in in his works. In this study, it is aimed to examine the perceptual problematic, which has developed in modern Turkish painting, on the basis of cultural phenomena. While making this study, examples from the works of modern Turkish artists were examined and the perceptual problematic on the basis of culture was tried to be determined. In general, modern Turkish painting has been greatly influenced by Western painters in its development process. Therefore, as the interaction of painters with their own cultures decreased, perceptual problems began to emerge. But over time, many painters realized this and started to reflect the Turkish culture in their paintings and even to synthesize it with the West. It is assumed that the emerging perceptual problematic will be resolved by taking cultural elements as a basis. In this context, this study examines modern Turkish painting within the framework of perception and culture with literature review and comparisons.

\section{Method}

\section{The Problem of Perception of the New, the Avant-Garde and the Protestant}

Basically, for an object to be an aesthetic object, it must be perceived by a subject. This situation clearly reveals the importance of perception. Perception, which makes objects meaningful, enables them to be grasped as a meaningful whole. If the situation is to be concretized with a very simple example, a table or a stove is distinguished by perception. Even in this simple example, it is clearly seen that the formation of perceptions as a quality was formed after the long trial and training process of humanity.

Hartmann, (Tunal1, 1996, p. 34-35) "It contains many things that are not generally grasped in the sensible perception in everyday perception. We enter a room, where we see poverty and wealth. We see a face or a person in motion, perhaps only from behind, but we learn directly about his spiritual life, his character and his destiny," he pointed out to the world of meaning hidden behind something material.

According to Merleau-Ponty (Gürsoy, 2007), perception is expressed as a ground where the connection between consciousness and the world, human and external environment is established and appears in the simplest way. In other words, the living body, by determining its status in life, perceives everything in the environment within daily experiences and personal and individual occurrences. Therefore, since the perceptions of people and therefore societies will change depending on the conditions, the relationship between the viewer, the artist and the work will be affected positively or negatively. Because the artist has a perception of his own.

The perception of the work in general necessitates that the perception be considered as a 'problematic' in the modernization process of the painting. The transformation of perception into a problematic can be explained more clearly with the metaphor of the perception of 'beautiful'. Because the concept of beauty, which changed in connection with the development of the ages, was a unifying 
concern trying to define the essence of classical beauty at first, but today it has turned into categories such as tragicomic, grotesque, sarcastic, protest and strange.

With the effect of developing technology, art has not only become accessible to everyone in the society, but it has also enabled the perception of the art product to change. This situation progressed in the same way for both the artist and the consumer, and perceptual changes and perceptual problems were mixed with each other. For example, music spread economically and mechanically has become live or recorded, and images have begun to be frozen. In general, it should be stated that perceptual changes and perceptual problems are also related to developments and innovations (Gombrich, 1992).

Greenberg (2008, p. 30-33) considers the avant-garde to be a rare phenomenon. Before the mid-19th century, nowhere else was the avant-garde resembling it, but then the avant-garde emerged as a threat and a challenge. The threat posed in the field of art lies in the fact that art production, no longer driven by the taste of a cultured elite, is increasingly exposed to the corruption of the market. The challenge to this situation is that, in order to maintain its own continuity, high art must, frankly, innovate more radically than it did even four centuries ago. The emerging avant-garde reconstructed the personalities of the painters like their works. This situation naturally affected the perceptions. On the other hand, artists have kept their own art away from this market by making innovations that are difficult to be perceived and noticed at first, even for the educated layer, in response to the emerging perceptual changes and the market. Despite all this, the perceptual difficulties that arise in recognizing innovations create problems that are difficult to overcome, but they have eased over time as they get used to the situation.

Clement Greenberg wrote in 1967, at the end of his essay 'Where is the Avangarde': "I have not explicitly taken into account that perhaps the avant-garde as a historical entity is indeed nearing its end. When that happens, high art production will have to be handled by someone else. Who the 'someone else' would be, I can't even imagine? However, I can see that the production of high art in general is coming to an end with avant-garde art. I am not saying that this will certainly be the case; I just think that something other than the avant-garde, that is, a dedicated, 'snobbish' elite, should, in one form or another, continue to produce high art in a society like ours." made the evaluation (Greenberg, 2008, p. 33).

All these developments in the world naturally also affected Turkish painters. With the difficulty of keeping up with the emerging changes, the painters experienced perceptual problems with the effect of cultural conflicts from time to time. However, the painters, who managed to synthesize the innovations that emerged with the culture in time, learned to cope with perceptual problems and taught them to the public.

\section{Relationship between Culture, Perception and Art}

When the relationship between culture, art and perception is examined, aesthetics emerges on the basis of all of them. In art education, aesthetics, essence and purpose have developed harmoniously, creating high qualities in an indirect way, apart from improving one's taste and aesthetic perception ability, enables imagination and thought to flourish (Eroğlu, 2006, p. 145). In this context, perception has a very important place in terms of both the artist and the society.

As a general concept, perception refers to the process of interpreting and making sense of things that people can obtain, find and discover by arranging. In other words, perception is to reach consciousness by grasping or comprehending that thing by directing all attention to a certain thing. The concept of perception, on the other hand, means distinctiveness and comprehension.

The way of perception, perception and point of view can differ from society to society and according to the characteristics of the artist. This difference stems from the perception of reality and reality. In this, first of all, belief, then culture and way of life are very effective. In Western civilization, truth and truth mean the same thing. Western societies deal with reality in object-form, based on the mimesis of Aristotle. Perception is based on the sensory image and sensations of the external structural features of objects and processes in the material world that directly affect the sense organs. The most important perceptions about knowing are visual perceptions, followed by tactile, auditory, etc. perceptions.

As you can see, perception is the basis of everything. Culture is also perceived through perception. Painters reflect cultural elements to their art to the extent they perceive it. Therefore, changes in Turkish culture over time have been very effective on perception. This effect dates back to the Ottoman Empire before Turkey. Because the roots of cultural changes go back to there. 
It is noteworthy that Classical, Baroque and Rococo styles, which were seen in the arts of European countries in the historical process, began to enter the Ottoman art intensively in this period. Westernization movements, which manifested themselves in the field of art, as in many other fields, had a great impact on the organization of artistic action after the 19th century. The phenomenon of westernization, along with the social metamorphosis in the groups supporting art education and art, went beyond being a new dress, a new sheath, which was put on the skeleton in the Ottoman style. This situation constitutes an important element of the nineteenth century cultural setting, the comprehensive sign system of cultural changes through which a new social order is communicated, reproduced and explored.

It is noteworthy that many objects belonging to cultural heritage are used in compositions in modern Turkish painting. These elements were used by many Turkish painters both in the early periods when the painting concept based on peinture was used and in the late 1950s. While this was done, images related to all of the Anatolian civilizations, which determined the shaping of Anatolian culture, were used in many studies. For example, inspirations from all civilizations, from the Mother Goddess statuette unearthed in Çatalhöyük belonging to the Neolithic period to Seljuk and Ottoman architectural structures, have begun to be used in works. However, their use has been possible over time by overcoming the perceptual problems and synthesizing the culture.

Turkish painting artist Mustafa Pilevneli (1940) is among the Turkish modern painters who carry the cultural heritage into painting. In the 1970s, the painter made a series of watercolor and engraving works based on the local culture of Anatolia, especially the interpretations of the Goddess, "Mother of Fertility" (Kybele). In these paintings made by the artist, he was not limited to the images of these images belonging to the cultural heritage, but also added his share of fantasy and interpretation and created a contemporary "Mother of Blessings". This exemplifies the synthesis of culture. The painter has solved the problem of perception and put culture into a new form in its own synthesis. In this context, in her paintings from Pleven, Kybele does not make an analogy of the Mother Goddess, but an imaginative interpretation of a modern painter. The Mother Goddess, which takes its source from Anatolia, appears in Pilevneli's works with her full-hipped, belly, and big-breasted image, but turns into a fertility phenomenon that encompasses all of the rich myths symbolized by the Romans as Magna Mater (Great Mother) and carved into stone by Anatolian cultures. However, the produced product actually has a structure that is far from the Mother Goddess herself, nor outside of her. Objects of cultural value dealt with in his works, as a reflection of the painter's inner world, gained a unique identity and became color, texture and tone. As a result, it has become a completely different work of art, shaped by visual shaping elements by adding meaning (Özsezgin, 1981). This is an indication that the problem of perception has been resolved in the context of cultural elements.

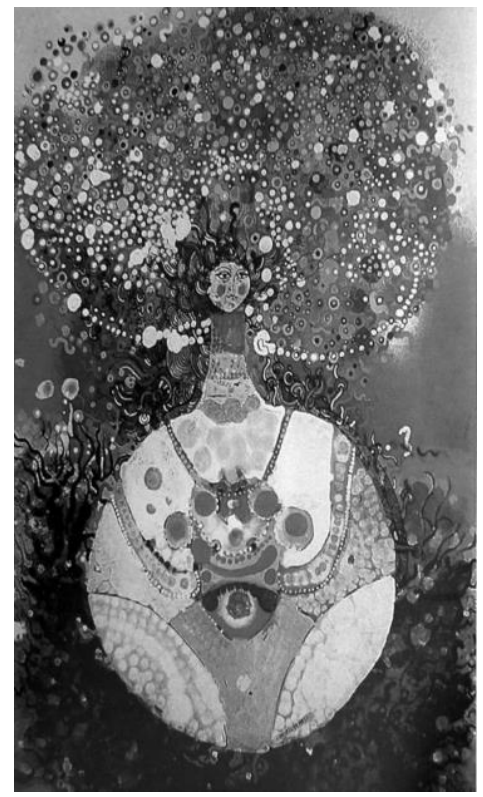

Picture 1. Mustafa Plevneli (Kibele, 1974)

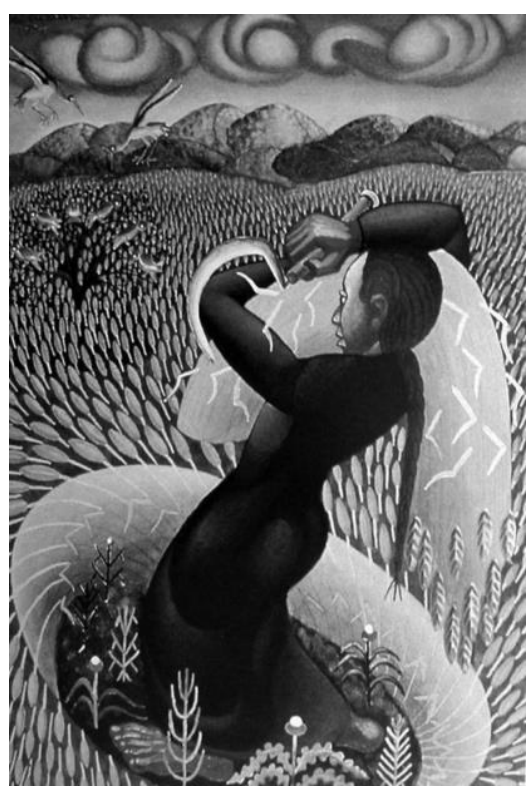

Picture 2. İbrahim Balaban (Bereket Ana, 1980) 
İbrahim Balaban (1921), who made paintings that reflect the realities of society or society, created a unique "naive" pictorial language inspired by the life of rural people in Anatolia, based on the sources of Anatolia. Inspired by the basic traditional structure of the people in terms of both form and content, the artist used the phenomena of human and society very strongly in his paintings (Berksoy, 1998, p. 111). He exhibited "Anatolian women with large bodies, huge hands and bare feet" in her exhibition titled "Age of Fertility", which she opened in "Istanbul Doku Art Gallery" in March 2004. In his paintings, the artist expressed the Anatolian woman as identical with the Mother Goddess figure. In this context, according to the artist, "women who collect spikes, throw sheafs on their backs, and breastfeed their children" are actually seen as today's "Mothers of Blessings". "The suffering but respectable mothers of Anatolia, who have faced the difficult living conditions and tried to carry the weight of agriculture on their backs" in the countryside are depicted as the Mother Goddesses of today on the artist's canvases (İndirkaş, 2001, p. 36). (Picture 2)

Painter, ceramicist and poet Bedri Rahmi Eyüboğlu (1911-1975), known for his works using traditional Turkish elements, has an important place in Turkish Painting Art. In the works of the artist, who was interested in folk rugs over time, motifs bearing the traces of folk culture attract attention. The influence of Fauvist painters in this formation is undeniable. As a matter of fact, Eyüboğlu's interest in Matisse and Dufy increased, and he began to study Eastern art, being somewhat influenced by their paintings. With the influence of his Anatolian trips, he started to include Anatolian subjects in his paintings. The image of Anatolian women in their local clothes is one of the themes that the artist frequently uses in his paintings (Picture 3). The rich motifs found in the clothes of Anatolian women as the accumulation of centuries have become indispensable images of the artist's paintings. While using these images, the artist wanted to reflect the Anatolian sensibility by using the technical possibilities of Western painting in his paintings (Dal, 1997, p. 573).

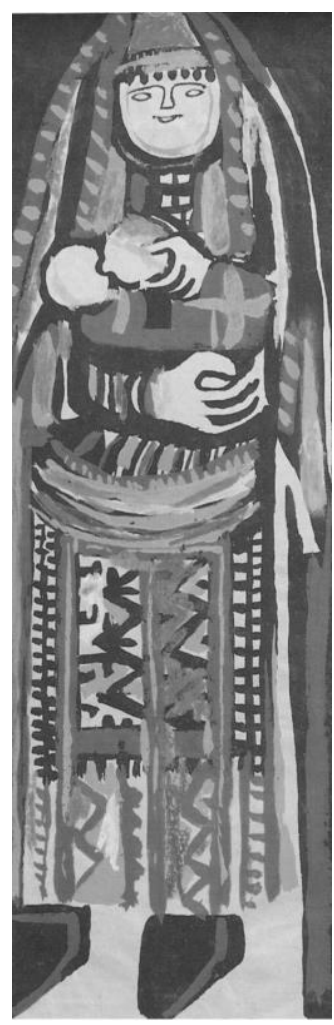

Picture 3. Bedri Rahmi Eyüboğlu Ayse Gelin, 1958.

While doing all this, Eyüboğlu has never discriminated against Anatolia's rich heritage. Because according to him, there is no difference between a Byzantine mosaic and a Sivas rug. The only difference between them was that the one knitted with stone loops, the other knitted with wool loops. Both of this basically express folk art and a culture. However, both were the product of a great tradition. Both had "values that are all of us". According to the artist, the products of folk art cannot be values that can be transferred as they are and repeated exactly. Contemporary painting dimensions and visual values should be added to the production process of the work (Özsezgin, 1981, p. 33). 
Adnan Çoker is another of the modern Turkish painters who created works based on the values belonging to the rich cultural heritage of Anatolia. Abstract works made by the artist for the first time were inspired by old writings. This situation can perhaps be considered as the beginning of the cultural heritage elements that will fully shape his art later on. On the other hand, the painter was influenced by the rhythm and form schemes in these old writings and integrated new, original compositions with the harmonies in his color collections (Ersoy, 1998, p. 40). In these abstraction works he has made, he aimed to reflect an understanding of order inspired by local architectural elements. The layout scheme, inspired by the arch and dome shapes of the local architecture, emerged in the artist's work in the 1960s. The painter, who examined Ottoman and especially Seljuk architectural structures from a painter's point of view between 1969-1984, tried to benefit from the monumentality of these structures. The painter found the secrets of obtaining geometric shape arrangements and color gradations on his own artistic development, in the source data of the architectural and geometric decoration of the Anatolian Seljuks (Tansuğ, 1986, p. 287). The gradient coloring method of a lighting system that can be called mystical, reaching from purple to white, generally achieves a musical rhythm flow that is desired to be brought to symmetrical form formations on a pitch-black background, but it is doubtful that the transcendent purpose to be emphasized in terms of content is achieved (Tansuğ, 1990, p. 44).

Only in this way was it possible to provide construction and spontaneity in abstraction. Regarding his work, the artist makes the following statements: "Ottoman architecture and Seljuk architecture are my sources. When these sources are used in painting, they illustrate a mystery that cannot be reached within the comprehensible aspects of geometry and light. Semi-circles, through-illuminated surfaces, vacuum colored voids, and horizontal, black or luminous bands used to dispel the slightest doubt of reference to reality (Kuban, 1994, p. 10).

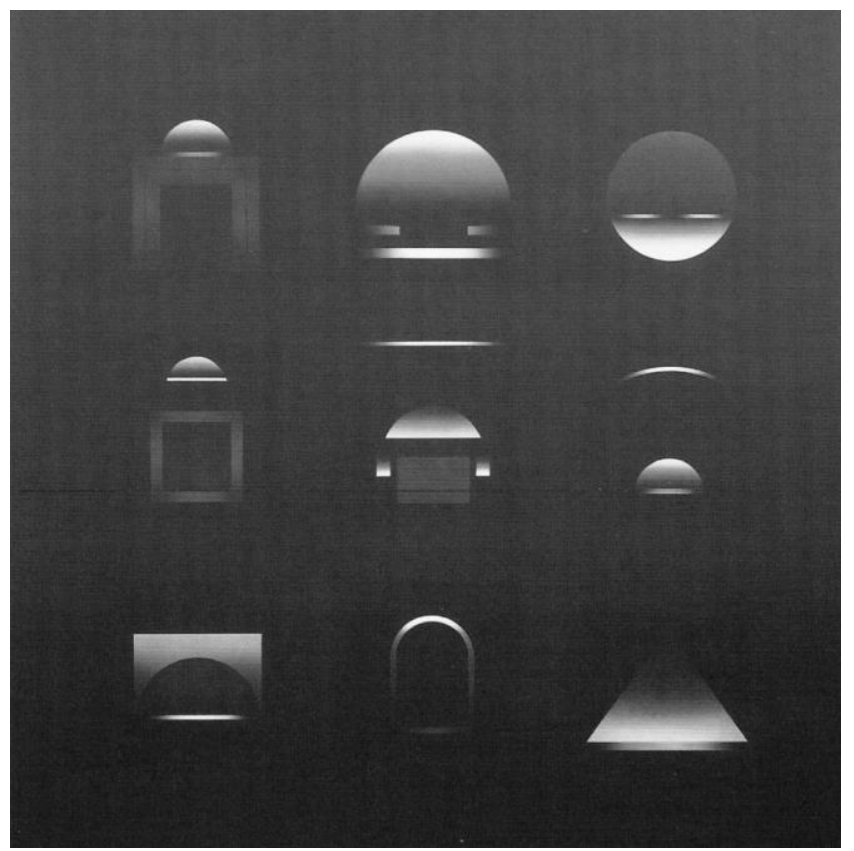

Picture 4. Adnan Coker, Retrospektif V, 1998

\section{Perception and Culture in Modern Turkish Painting}

According to Batur (1995), who dealt with how the contemporary world painting art was shaped, America became a center of attraction for artists with the effect of the second world war, and the greatest artists of the period in all European capitals immigrated to America. In terms of style, technique, material and discourse, the most diverse artistic productions of history began to emerge from here. Art, which "immigrated" from Europe to America, spread from there to Europe and then to the whole world. Istanbul is one of them. As in the rest of the world, in Turkey today, although all kinds of techniques and styles from the West, from canvas painting to ready-made objects, find supporters, the art environment is shaped by similar concerns with the West (İskender, 1988). 
ÇíçEK

Batur made an important experiment on the subject. He added a work of three leading Turkish painters with different tendencies, and three different foreign artists' work, which technically resembles them almost as if they were made by the same hand, but did not comment. Although he left the interpretation to the viewer, it is clear that his aim is to show that they are all part of Western-centered art, rather than who is influenced by whom. This is especially important when it comes to culture and perception in Turkish painting. These examples are presented below in order to better understand the perceptions of Turkish painters (Batur, 1995).

Instead of the above-mentioned Turkish painters who prioritize their own culture, they paint based on the culture abroad. Two examples were shared in order to reveal the difference in perception among these painters. These examples are shared below in order to better understand the perspectives of Turkish painters on perception and culture. Mixed Technique Works of Bedri Baykam and Julian Schnabel, painters of two different cultures (Pictures 5, 6) are shared below (Batur, 1995).

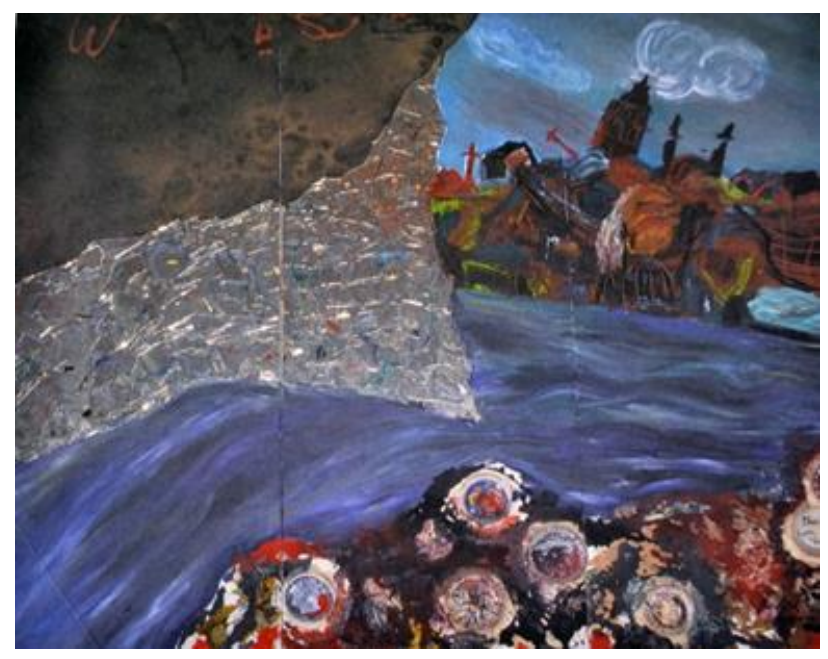

Picture 5. Bedri Baykam, İstanbul Boğar, 1991

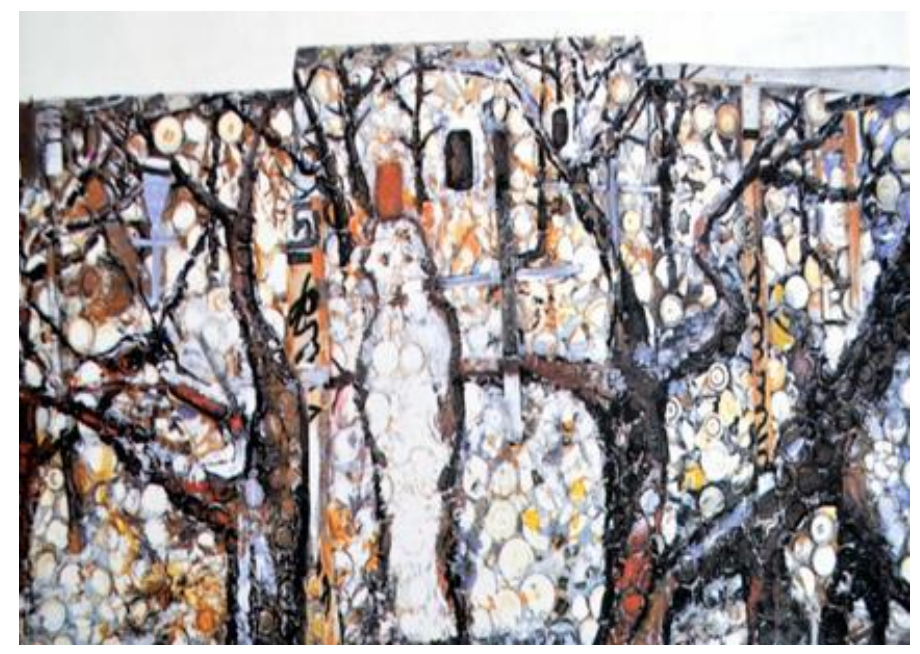

Picture 6. Julian Schnabel, Prag Ögrencisi, 1983

The common feature of both works is that they were made with paint and three-dimensional collage, in other words assemblage technique, and that round-shaped objects were glued like medallions or plates. The collage technique is a technique that Picasso started long before these artists, that Picasso started in 1913, that Schwiters used in almost every work since 1939, and that Rauschenberg developed it in 1961 by adding three-dimensional objects (Batur, 1995).

Another example is Installation, also known as Installation, by Sarkis and Jennifer Bartlett (Pictures 7, 8). The work titled "Luxembourg Garden" (1985), made by Bartlett, consists of a boat with a sail mast, which refers to the park area called "Luxemburg Garden" in Paris, which contains many works of contemporary art. The picture represents the toy sails, which are the symbol of the lake in the park. In the exhibition "Saturn in Europe" made by Sarkis, his work "The Meeting of Böcklin and Sarkis" (1989) refers 
to the oil painting "Island of the Dead" by Swiss painter Arnold Böcklin. The work consists of a boat with a sail mast, which represents the boat in the table. The only difference between the two works, made with the same material and logic, is only their stories. Although it does not matter who is affected by whom in studies conducted on similar dates, the origin of the installation technique that they both made dates back to Duchamp, but its widespread use dates back to the early 1970s until today (Batur, 1995).

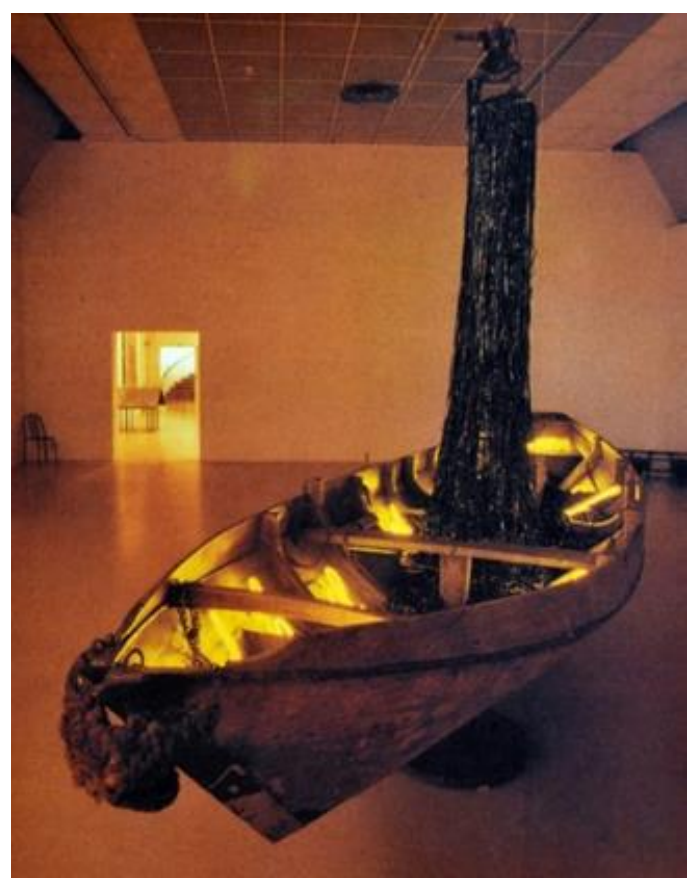

Picture 7. Sarkis, Böcklin'le Sarkisin Bulusması“ Avrupa'da Satürn”, 1989

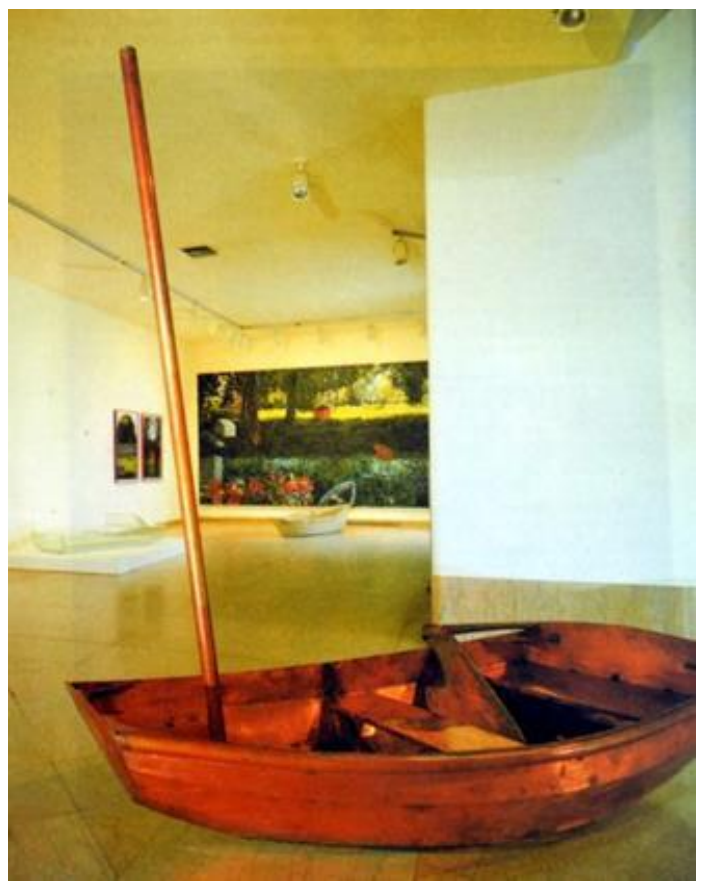

Picture 8. Jennifer Bertlett, Lülksemburg Bahcesi, 1987

Both Turkish painters in the examples are artists who can be called milestones in the development of Turkish contemporary painting and have introduced themselves at the international level. Baykam and Sarkis made great contributions to the recognition of innovations in contemporary world art in Turkey, even in times when mass media were not as developed as they are today. In addition, Sarkis is the only Turkish painter to represent our country at the 56th Venice Biennale held in 2015. With this awareness, the sampling of these two painters, each of whom has reached a certain level in their own style, is because 
they are typical examples of the "highest level" in terms of showing the place of Turkish art on the world scale. However, as can be seen from the examples, although Turkish painters have developed their own "individual interpretations", they are not actually the main creators of styles in technical terms. This is related to culture and perception. These famous Turkish painters preferred world-famous techniques to their own culture in the context of their own perceptions. Although masterpieces have emerged, they are basically far from Turkish perception and culture (İskender, 1988).

\section{Conclusion and Evaluation}

It is not possible to explain artistic developments independently of the society in which they flourished. Because art is an indicator of the mentality formed by the social, economic, cultural and religious accumulation of a society. There is a philosophical view and thought structure at the core of every art movement. Perceiving the formal features of a work of art, its understanding of color and line, means grasping its external appearance. In order to grasp the essence of the artistic product, it is necessary to understand and analyze the spiritual, social and cultural structure of the environment that created it (Giray, 1997, p. 281).

Within the scope of this research, it is aimed to understand the relationship between concepts such as culture, perception and modern Turkish artists. In this context, it has been tried to reveal how the elements that make up the culture are reflected in the works of the painters and how they are perceived by the painters with the help of various examples. As members of the society and culture they live in, artists have always been affected by the cultural structure and its carrier element, the cultural heritage, and somehow also affected this cultural heritage. This situation is also reflected in the works of painters. However, the difference in perception between the painters in the context of culture has led to the diversification of the works, and sometimes distances and convergences have emerged from cultural ties.

\section{Ethical Statement}

In the writing process of the study titled "Cultural Evaluation of Perceptual Problems in Modern Turkish Painting" scientific rules, ethics and quotation rules were followed; No falsification has been made on the collected data and this study has not been sent to any other academic publication environment for evaluation. Since the document analysis is examined in this study, there is no requirement for an ethics committee decision.

\section{References}

Anonim, (1995). Sanatdünyamıそ, avant-garde 1945-1995. Son yarm yüzynlın sanat akımlar, kavramları (Say1 59). İstanbul: Yap1 Kredi Yayınlar1.

Berksoy, F. (1998). 20. yüzynl batı ve Türk resminde toplumsal gerçekçilik. İstanbul: Bakışlar Matbaacilık.

Eroğlu, Ö. (2006). Resim sanatı sözliüği. İstanbul: Nelli Sanat Evi Yayınları.

Dal, E. (1997). Tollu, Cemal. İstanbul: Eczacıbaşı Sanat Ansiklopedisi III, Yem Yayın.

Ersoy, A. (1998). 1950'den 2000'e günümüz Türk resim sanatı. İstanbul: Bilim Sanat Galerisi.

Giray K. (1997). Müstakil ressamlar ve heykelttraşlar birliği. İstanbul: Akbank Kültür ve Sanat Kitapları.

Greenberg, C. (1967). Greenberg, Clement; Where is the Avangarde?, Vogne. Artist Actual, Mart, 28-33.

Gürsoy, K. (2007). Maurice Merleau-Ponty'de Algz Problemine Giriş, (1. Baskı). Ankara: Lotus Yayınevi.

Güvenç, B. (1996). İnsan ve kültür (7. Basım). İstanbul: Remzi Yayınevi.

İndirkaş, Z. (2001). Ana tanrı̧alar, kybele ve çağdas Türk resmindeki iə̨düs̆̈̈mleri (1. Baskı). Ankara: Kültür Bakanlı̆̆1 Yayinları.

İskender, K. (1988). Türk resminin dünü, bugünü ve geleceği. Gerge-dan Kültür ve Sanat Dergisi, Türk Resim Sanat1 Özel Say1s1.

Kuban, D. (1994). Coker'in ışıkl geometrisi, Adnan Çoker minimaller ve varyasyonlar. İstanbul: Galeri B Yayınları.

Özsezgin, K. (1981). Başlangicından bugüne çağdas Türk resim sanatı taribi III. İstanbul: Tiglat Basımevi,.

Tansuğ, S. (1986). Çăgdaş Türk sanatı (I. Basım), İstanbul: Remzi Kitabevi.

Tansuğ, S. (1990). Türk resminde yeni dönem. İstanbul: Remzi Kitabevi.

Topçu, N. (1998). Kültür ve medeniyet (II. Bask1). İstanbul: Dergâh Yayınları.

Tunalı, İ. (1996). Grek estetik'i (4. Baski). İstanbul: Remzi Kitabevi.

Turhan, M. (2002). Kültür değismeleri (Sosyal psikoloji bakımından bir tetkike) (IV. Baskı). İstanbul: Çamlıca Yayınları.

\section{TÜRKÇE GENİ̧̧ ÖZET}

Modern sanatın tarihsel süreç içerisindeki gelişimi, Batılı ülkelerin yüzlerce senelik geçmişlerine karşlık, Türk resminde ortalama yüz- yüz elli senelik bir süreç bulunmaktadır. Bu önemli ayrıma karşılık, bugün Türk resminin ulaştığı nokta hiç de azımsanmayacak bir seviyedir. Türkiye’de dünya çapında bilinen 
pek çok sanatçı yetişmiştir. Bütün bunlara karşın Türk resmi hala olması gereken yere ulaşmamış ve Türk ressamları "baş yapıtt" denilecek eserler üretememiştir. Bu durumun temel nedeni olarak bu çalışmada algisal sorunsalın olduğu düşünülmektedir. Çünkü Türk resmi Ankara, İstanbul ve İzmir gibi genelde üç büyük şehir arasında sınırlı kalmıştır. Dolayısıyla genel olarak ressamlar Türk kültürünün taşıyıcı sahası olarak görülen Anadolu kültürüne çok yakın durmayıp, kendi kültürel köklerinden olması gerektiği kadar yararlanamamıştır ve sonuçta kendi kültürleri ile yeterince etkileşimde bulunmadıkları için ortaya algısal sorunsalın çıkmışır.

Modern Türk resmindeki algısal sorunsalın kültürel açıdan değerlendirilmesi temeline dayanan bu araştırmada literatür taraması yöntem olarak kullanılmıştır. Taramanın sonuçlarına göre, gün geçtikçe ressamların kendi kültürlerine yaklaşması ve geleneksel öğelerle modern öğeleri sentezlemeleri sayesinde kültürel kapsamdaki algısal sorunsal aşılmaya başlamıştır. Zaman içerisinde Türk resminin uluslararası platformda da ilerleyip ivme sağlayacağı düşünülmektedir. Kültürel açıdan Türkler dünyadaki en zengin ve köklü mirasa sahiptirler. Dolayısıyla, pek çok medeniyete ev sahipliği yapan Türklerin kültürel toprakları zaman içerisinde ressamlar içinde ilham kaynağı haline gelip bugüne dek aşılamayan algısal sorunların aşılacağına kanaat getirilmiştir.

En çok tanımlanan kavramlardan biri kültürdür. Pek çok araştırmacı ve düşünür, kendi yaklaşımları bağlamında kültürün çeşitli tanımlarını yapmışlardır. Konuyla ilgili çalısmalar yapan arastırmacılar, günlük yaşamda hem yaşam biçiminin hem de düşünce, sanat, edebiyat, din, neşe ve eğlence yapısının temel belirleyicisinin kültür dünyası olduğunu belirtmektedirler. Tüm tarihsel süreç boyunca insanın dünya doğasını ve kendini yönetmeyi öğrenerek kendi yarattığı dünyasını bir eser olarak kabul etmiş bu öngörü ile çalışmalar ortaya koymuşlardır.

Kültür, bir toplumun ya da insanların yaşam biçimi olarak kabul edilir. Kültür kavramını, bilgi, inanç, sanat, ahlak, gelenekler, bireyin ait olduğu değerler idesinin toplumun bir üyesi olarak edindiği birikimler ve diğer tüm ilgi alanlarını içeren çok karmaşı bir bütün olarak karşımıza çıkmakta ve bu gelenekte eserler ortaya konulmaktadır.

Kuşaktan kuşağa aktarılan değerler bütünü olarak da kabul edilen kültür kavramı, bir toplumun tüm üyelerinin olayları karşılayan algıları ile tarihsel süreç içinde sahip oldukları değer yargılarıdır. Bu değerler bilim, felsefe, sanat ve din tarafindan yaşatılır. Görüldüğü gibi kültür, toplumun yapı taşı olduğu için sanat ve sanatçlar için çok önemli ve gerekli bir olgudur.

Genel olarak sanatın her alanında sanatçı, içinde bulunduğu kültürden beslenir. Sanatçı, içinde yaşadığı toplumun bir bireyi ise, yaşadığı toplumun kültürel yapısının izlerini görmek kaçınılmazdır. $\mathrm{Bu}$ çalışmada modern Türk resminde gelişen alg1 sorunsalının kültürel olgular temelinde incelenmesi amaçlanmaktadır. Bu çalışma yapilırken çağdaş Türk sanatçılarının eserlerinden örnekler incelenmiş ve kültür temelli alg1 sorunsalları belirlenmeye çalş̧1mıştır. Genel olarak modern Türk resmi, gelişim sürecinde Batılı ressamlardan büyük ölçüde etkilenmiştir. Dolayısıyla ressamların kendi kültürleriyle etkileşimi azaldıkça algısal sorunlar ortaya çıkmaya başladığını görmekteyız. Ancak zamanla birçok ressam bunun farkına vararak Türk kültürünü resimlerine yansıtmaya ve hatta Batı ile sentezlemeye başlayıp. Ortaya çıkan alg1 sorunsalının kültürel unsurlar temel alınarak çözüleceği varsayılmaktadır. Bu bağlamda bu çalışma, modern Türk resmini alg1 ve kültür çerçevesinde literatür taraması ve karşılaştırmalarla incelemektedir.

Çağdaş dünya resim sanatının nasıl şekillendiğini ele alan sanatçlara göre Amerika, ikinci dünya savaşının etkisiyle sanatçılar için bir çekim merkezi haline gelmiş ve tüm Avrupa başkentlerinde dönemin en büyük sanatçıları Amerika'ya göç etmiştir. Üslup, teknik, malzeme ve söylem açısından tarihin en çeşitli sanatsal üretimleri buradan ortaya çıkmaya başladığını kabul etmektedirler. Avrupa'dan Amerika'ya "göç eden" sanat, oradan Avrupa'ya ve oradan da tüm dünyaya yayıldı. İstanbul'da bunlardan biri. Tüm dünyada olduğu gibi bugün Türkiye'de de Batı'dan tuval resminden hazır objelere kadar her türlü teknik ve üslup destek bulsa da sanat ortamı Batı ile benzer kaygılarla şekilleniyor.

Sanatsal gelişmeleri içinde geliştikleri toplumdan bağımsız olarak açıklamak mümkün değildir. Çünkü sanat, bir toplumun sosyal, ekonomik, kültürel ve dini birikiminin oluşturduğu zihniyetin bir göstergesidir. Her sanat akımının özünde felsefi bir görüş ve düşünce yapısı vardır. Bir sanat eserinin biçimsel özelliklerini, renk ve çizgi anlayışını algılamak, onun dış görünüşünü kavramak demektir. Sanatsal ürünün özünü kavrayabilmek için onu oluşturan çevrenin ruhsal, sosyal ve kültürel yapısını anlamak ve analiz etmek gerekir. 
ÇiÇEK

Cultural Evaluation of Perceptual Problems in Modern Turkish Painting

$\mathrm{Bu}$ araştırma kapsamında kültür, alg1 ve çağdaş Türk sanatçıları gibi kavramlar arasındaki ilişkinin anlaşılması amaçlanmaktadır. Bu bağlamda kültürü oluşturan unsurların ressamların eserlerine nasıl yansıdığı ve ressamlar tarafından nasıl algılandığı çeşitli örnekler yardımıyla ortaya konulmaya çalışılmıştır. Sanatçılar, içinde yaşadıkları toplumun ve kültürün birer üyesi olarak kültürel yapı ve onun taşıyıcı unsuru olan kültürel mirastan her zaman etkilenmişler ve bir şekilde bu kültürel mirası da etkilemişlerdir. $\mathrm{Bu}$ durum ressamların eserlerine de yansımıştır. Ancak kültür bağlamında ressamlar arasındaki algı farklılı̆g eserlerin çeşitlenmesine yol açmış, bazen kültürel bağlardan mesafeler ve yakınlaşmalar ortaya çıkmıştır. 